\author{
Mirosława Szark-Eckardt, ${ }^{1}$ Beata Augustyńska, ${ }^{2}$ \\ Wioletta Łubkowska ${ }^{3}$ \\ ${ }^{1}$ Kazimierz Wielki University in Bydgoszcz \\ Faculty of Physical Education, Health and Tourism \\ e-mail: szark@ukw.edu.pl \\ ${ }^{2}$ Kazimierz Wielki University in Bydgoszcz \\ Faculty of Physical Education, Health and Tourism \\ e-mail: augustynska@op.pl \\ ${ }^{3}$ University of Szczecin \\ Faculty of Physical Education and Health Promotion \\ e-mail: wioletta.lubkowska@usz.edu.pl
}

\title{
Reasons behind Studying Tourism and Recreation and Career Plans of Undergraduate Students
}

JEL codes: I25, J24

Keywords: reasons, choosing fields of study, satisfaction with studies, career plans

Summary. The aim of the study was to determine the reasons behind studying and career plans of undergraduate students of tourism and recreation at the University of Bydgoszcz. For the statistical inference, the incidence of features and the chi-square test for independence were used. 136 respondents (69\% women and $31 \%$ men) were chosen by non-probability sampling. The analysis of relations between the year of studies and the reasons behind choosing that field of study showed a statistically significant difference in terms of expectations of $1^{\text {st }}-, 2^{\text {nd }}$ - and $3^{\text {rd }}$-year students for an interesting job $(p=0.033)$. Statistically significant relationships among students of various years were found in terms to their plans for growth opportunities in the tourism sector $(\mathrm{p}=0.028)$. An important reason behind choosing tourism and recreation was a prospect of running one's own business in the area. Career plans and future work in the recreation sector motivated the $2^{\text {nd }}$ - and $3^{\text {rd }}$-year students to believe that they would hypothetically select that field of study again. 


\section{Introduction}

Motivation is a force that determines human behavior and affects people's decisions. The word "motivation" comes from the Latin verb movere, i.e. "to move", "to push". In the literature, one can find many various attempts to pinpoint the term "motivation". It is a concept with many different meanings, with a very broad and imprecise interpretation (Kacprzak-Biernacka, Skura-Madziała, Kopański, Brukwicka, Lishchynskyy, Mazurek, 2014). In this paper, motivation is defined as a process which produces, directs and sustains certain human behavior amongst other alternative forms of behavior in order to achieve certain goals.

The terms "motivation" and "motive" are often used interchangeably. Obuchowski (1993, p. 4) notes that often no distinction is made between "motive" and "motivation", using only "motivation". Motive creates a feeling of justification to take up certain action. Moreover, it impacts changes of decisions of an individual in the course to reaching their target. Thus, it plays a regulatory function, involving the adaptation of forms of activities to the changing requirements, so that certain standard or an established state of affairs can be achieved.

In this paper a broad understanding of motivating and motives was used (i.e. attempts to reach one's goals). Given Poland's labor market situation, which is also a result of opening up of borders and possibility to work in other countries of the European Union, it is interesting to determine motivation of students who take up higher education. Asking for reasons behind seeking higher education is synonymous with asking for value of education in today's world.

Some authors of scientific papers (Korpysa, 2008) relate motivation to entrepreneurial attitudes and interpersonal skills (De Carolis, Saparito, 2006; Krueger, Brazeal, 1994; Paczyńska-Jędrycka, Łubkowska, Jońca, 2015). Others state that willingness to pursue higher education is a symptom of entrepreneurial mindset (Haczek, Kłos, 2012; Klimkowska, 2014). One can distinguish a wide variety of conditions and determinants that influence the decision of completing higher education. According to some researchers, decision to study is related to the choice of a particular field of study. This decision determines not only the educational path of a young person, but also - to a large extent - their choice of profession (Buchta, Skiert, 2008). Motivation to act, learn and deepen one's knowledge and the ability to determine one's interest (Buchta, Skiert, 2009; Haczek, Kłos, 2012; Radzińska, Nowak, Nowak, 2016a) and, consequently, select the field of study which agrees with one's interests, determines the academic success (Haczek, Kłos, 2012; Jarecki, 2008).

Research in this area has been conducted in Poland since the 1970s. At that time, the most important motivation for studying was by far deepening one's knowledge and professional prospects. Third place was occupied by the prestige of higher education (Liberska, 1974). Interesting research on this subject was 
conducted by Jarecki (2008). His results showed that over the years the motivation of students has changed. Previously, the main reason behind choosing higher education was development of one's interests, while now pragmatic considerations are dominant, i.e. promising job prospects. The same author underlines that there is wide variation between the motives and their importance in the selection of various fields of study.

Nowadays, young people plan their careers in various ways. Young Poles, just like their peers in more developed countries, consider career in terms of developmental challenges and the basic tasks attributable to this period of life which is the transition to adulthood and gaining independence.

For many years, higher education sector has witnessed a growing number of universities, both public and private. Unprecedented number of young people decided to take up higher education. Recent years, however, have brought a slowdown of this process due to the demographic decline. From 2010, a gradual slowdown was recorded, and the number of students in public and private schools decreased (Łubkowska, Eider, 2014; Skiert, Buchta, 2014).

The subject matter of this paper concerns the field of Tourism and Recreation (hereinafter: T\&R). Forecasts saying that universities will feel the effects of demographic decline until 2025 are also valid for T\&R. In recent years, a number of students who commenced their T\&R studies has visibly declined. This situation forces universities to seek ways to promote their courses and systematically adapt to expectations of students.

The aim of this study was to determine the reasons behind studying and career plans of undergraduate students of Tourism and Recreation at the University of Bydgoszcz.

\section{Material and methods}

The results of this study constitute a portion of a project on evaluation of education quality at Tourism and Recreation faculties, offered by two universities: Kazimierz Wielki University in Bydgoszcz (Department of Physical Education, Health and Tourism) (Szark-Eckardt, Augustyńska, Łubkowska, Nowak, 2017) and the University of Szczecin (Faculty of Physical Culture and Health Promotion) (Łubkowska, Nadobnik, Tarnowski, Nowak, 2017; Nadobnik, Tarnowski, Nowak, 2017).

The study, which was conducted in June 2016, covered 136 full-time undergraduate students of Tourism and Recreation at the University of Bydgoszcz. The group consisted of $69 \%$ of women and $31 \%$ of men. Slightly over $22 \%$ of students came from rural areas, while nearly $78 \%$ reported urban origin. Almost $17 \%$ of students from rural areas were female, while $5.2 \%$ of the total were male. In urban environments, the share of female students amounted to $51.5 \%$ of the 
respondents, while the share of male students was $25.9 \%$ of the total. The structure of the surveyed population of young people, carried out according to the criterion of the year of study, showed that $29.4 \%$ of all respondents were $1^{\text {st }}$-year students, $30.9 \%$ of them were $2^{\text {nd }}$-year students, while $39.7 \%$ of them were $3^{\text {rd }}$-year students. Analysis of affluence of the student families by place of residence did not show statistically significant differences. Most of the respondents (51.5\%) rated the financial situation of their family as "very good". Among students living permanently in the countryside, $54.8 \%$ of them considered the situation of the family as "very good". Similar declarations were made by $50.5 \%$ of students living in cities. No "bad" or "very bad" financial situations were reported. Positive assessment of financial situation of students' families may indicate a relatively favorable financial situation of the families.

In the research, the method of diagnostic survey was used which incorporated auditorium questionnaire, uncategorized interview and document analysis. The primary research tool was a questionnaire prepared by Nowak (Szark-Eckardt, et al., 2017). Empirical data was analyzed statistically using SPSS 23 (IBM USA). Characteristics of the distribution of responses were established, as well as significance of differences on the basis of the chi-square test for independence. Statistically significant indicators had to meet the condition of $\mathrm{p} \leq 0.05$.

\section{Results}

The analysis of motivation for studying Tourism and Recreation took into account the fact that the study was retrospective. The following question was asked: How do students of various years perceive their choice and continuation of Tourism and Recreation studies, given their participation in the classes? The results are shown in Table 1.

Passion for travel and desire to explore the world were reported by $76.5 \%$ of respondents. Year of study did not differentiate the answers to a significant level.

While analyzing the choice and continuation of education by students of various years, influenced by their participation in the classes, a statistically significant difference was determined in the motives of $1^{\text {st }}, 2^{\text {nd }}$ - and $3^{\text {rd }}$-year students in terms of prospects for an interesting job $(\mathrm{p}=0.033)$. Among all respondents, 54.5\% indicated this factor as an important motive. Prospects of an interesting job motivated most often $1^{\text {st }}$ - and $2^{\text {nd }}$ - year students ( 65 and $61.9 \%$, respectively). Among $3^{\text {rd }}$-year students, this motive seemed to lose its importance (40.7\%). Hence, this motive tended to weaken among students of subsequent years. Statistically significant relationships among students of various years were found, which were related to their plans for growth opportunities in the tourism sector $(\mathrm{p}=0.028)$. This motive was important for $34.6 \%$ of respondents. Development opportunities in the tourism industry were an important selection criterion mainly for $2^{\text {nd }}$-year students $(50 \%)$. It was evaluated much lower by students of the $1^{\text {st }}$ and $3^{\text {rd }}$ year. 
Table 1

The motives for the choice of the course and commencing studies at the faculty of tourism and recreation (chi-square test of independence $\chi^{2}$ )

\begin{tabular}{|c|c|c|c|c|c|c|}
\hline \multirow{3}{*}{ Motives } & \multicolumn{5}{|c|}{ Year of study } & \multirow{3}{*}{$\begin{array}{c}\mathrm{p} \\
\text { for } \chi^{2}\end{array}$} \\
\hline & $\begin{array}{c}\mathrm{I} \\
(\mathrm{n}=40)\end{array}$ & $\begin{array}{c}\text { II } \\
(n=42)\end{array}$ & $\begin{array}{c}\text { III } \\
(\mathrm{n}=54)\end{array}$ & \multicolumn{2}{|c|}{ total } & \\
\hline & \multicolumn{3}{|c|}{$\%$} & $\mathrm{n}$ & $\%$ & \\
\hline $\begin{array}{l}\text { Passion for travel and desire to explore the } \\
\text { world }\end{array}$ & 87.5 & 76.2 & 68.5 & 104 & 76.5 & 0.100 \\
\hline Prospects of an interesting job ${ }^{*}$ & 65.0 & 61.9 & 40.7 & 74 & 54.4 & $\mathbf{0 . 0 3 3}$ \\
\hline Prospects of working in a tourist facility & 55.0 & 50.0 & 44.4 & 67 & 49.3 & 0.595 \\
\hline Interest in physical recreation & 42.5 & 47.6 & 46.3 & 62 & 45.6 & 0.889 \\
\hline Belief in attractiveness of this field of study & 32.5 & 45.2 & 38.9 & 53 & 39.0 & 0.497 \\
\hline $\begin{array}{l}\text { Prospects of working in a recreational } \\
\text { facility }\end{array}$ & 45.0 & 45.2 & 29.6 & 53 & 39.0 & 0.193 \\
\hline Growth opportunities in the tourism sector ${ }^{*}$ & 32.5 & 50.0 & 24.1 & 47 & 34.6 & 0.028 \\
\hline Opportunity to run own tourism business & 42.5 & 35.7 & 22.2 & 44 & 32.4 & 0.099 \\
\hline $\begin{array}{l}\text { Desire to promote a healthy lifestyle through } \\
\text { active recreation }\end{array}$ & 35.0 & 35.7 & 27.8 & 44 & 32.4 & 0.650 \\
\hline Own experience of international travel & 32.5 & 38.1 & 20.4 & 40 & 29.4 & 0.147 \\
\hline Need to complete any higher education at all & 22.5 & 35.7 & 24.1 & 37 & 27.2 & 0.325 \\
\hline Predisposition to work with people & 30.0 & 31.0 & 20.4 & 36 & 26.5 & 0.423 \\
\hline Own experience of domestic travel & 27.5 & 28.6 & 22.2 & 35 & 25.7 & 0.744 \\
\hline $\begin{array}{l}\text { Belief that getting into university and } \\
\text { studying is not difficult }\end{array}$ & 17.5 & 31.0 & 25.9 & 34 & 25.0 & 0.365 \\
\hline Opportunity to run own recreation business & 22.5 & 23.8 & 11.1 & 25 & 18.4 & 0.204 \\
\hline Practicing qualified tourism & 22.5 & 21.4 & 7.4 & 22 & 16.2 & 0.078 \\
\hline $\begin{array}{l}\text { Willingness to work in other tourist and } \\
\text { recreational institutions }\end{array}$ & 17.5 & 14.3 & 13 & 20 & 14.7 & 0.852 \\
\hline Lower cost of living compared to other cities & 10.0 & 19.0 & 14.8 & 20 & 14.7 & 0.513 \\
\hline Influence of friends, acquaintances, parents & 10.0 & 7.1 & 11.1 & 13 & 9.6 & 0.801 \\
\hline $\begin{array}{l}\text { Belief in high social prestige of this } \\
\text { profession }\end{array}$ & 10.0 & 7.1 & 5.6 & 10 & 7.4 & 0.715 \\
\hline
\end{tabular}

${ }^{*}$ Statistical significance for the motives: prospects of an interesting job $(p=0.033)$; growth opportunities in the tourism sector $(\mathrm{p}=0.028)$.

Source: author's own research.

Statistically significant relationships among students of different years were found, which were related to their plans for growth opportunities in the tourism sector $(\mathrm{p}=0.028)$. This motive was important for $34.6 \%$ of respondents. Development opportunities in the tourism industry were an important selection criterion mainly for $2^{\text {nd }}$-year students $(50 \%)$. It was evaluated much lower by students of the $1^{\text {st }}$ and $3^{\text {rd }}$ year. On average, every third $1^{\text {st }}$-year student and only one in four $3^{\text {rd }}$-year student reported this motive as important (Table 1). 
Working in the tourism sector and interest in physical recreation were important reasons to choose and study Tourism and Recreation (49.3 and $45.6 \%$, respectively), but they did not differentiate various years of students. Almost every third respondent's decision was influenced by a desire to promote healthy lifestyle through active recreation, as well as a chance to run their own business in the field of tourism (32.4\% each). Belief in growth opportunities in the industry varied by year of study $(42.5,35.7$ and $22.2 \%$, respectively), but was statistically insignificant. Predisposition to work with people and experience in travelling abroad were least important for $3^{\text {rd }}$-year students. Among all respondents, the need to obtain any higher education diploma and belief in the attractiveness of studies was reported by every third student ( 27.2 and 39\%, respectively). Meanwhile, every fourth respondent $(25 \%)$ was motivated by easy access and simplicity of curriculum. High prestige of the profession motivated few respondents (7.4\%) (Table 1).

Satisfaction with studies (Table 2) was expressed mainly by students of the third year whose choice and continuation of that particular field of study was motivated by sports: practicing qualified tourism $(\mathrm{p}=0.006)$, interest in physical recreation $(\mathrm{p}=0.029)$, and career-oriented plans - working in the recreation sector $(\mathrm{p}=0.026)$.

Table 2

The motives for choosing the field of study and commencing studies, satisfaction with the studies and a declaration of choosing this faculty again* (Chi-squared test $\left.\chi^{2}\right)$

\begin{tabular}{|l|c|c|c|c|c|c|}
\hline \multirow{2}{*}{ Motives } & \multicolumn{3}{c|}{$\begin{array}{c}\text { Satisfaction with studies } \\
\text { (year of study) }\end{array}$} & \multicolumn{3}{c|}{$\begin{array}{c}\text { Declaration of choosing } \\
\text { the faculty again (year) }\end{array}$} \\
\cline { 2 - 7 } & $1^{\text {st }}$ year & $2^{\text {nd }}$ year & $3^{\text {rd }}$ year & $1^{\text {st }}$ year & $2^{\text {nd }}$ year & $3^{\text {rd }}$ year \\
\hline Work in the recreation sector & & & 0.026 & & & \\
\hline Interest in physical recreation & & & 0.029 & & & \\
\hline $\begin{array}{l}\text { Desire to promote a healthy lifestyle } \\
\text { through active recreation }\end{array}$ & & & & & & 0.038 \\
\hline Practicing qualified tourism & & & 0.006 & & & \\
\hline Own tourist experience - abroad & & & & 0.045 & & \\
\hline
\end{tabular}

* For improved clarity, the table contains only those variables and values which differentiated respondents' opinions to a statistically significant extent.

Source: author's own research.

For the third-year students who were satisfied with their studies, external motives - friends' persuasion - were important $(\mathrm{p}=0.040)$. Only $1^{\text {st }}$-year students expressed satisfaction with their studies and declared choosing them again $(p=0.006$ and $p=0.040$, respectively). Choosing the same field of study again by $1^{\text {st }}$-year was motivated by professional consideration - their own experience of travelling abroad $(p=0.045)$. The same field of study would be hypothetically 
selected again by $3^{\text {rd }}$-year students who were motivated by the desire to promote a healthy way of life through active recreation $(p=0.038)$ (Table 2$)$.

Table 3 presents an analysis of professional expectations of students of various years. Most respondents would like to work in the recreation sector (53\%).

Table 3

Career plans of the students of tourism and recreation considering the year of study (Chi-squared test $\chi^{2}$ )

\begin{tabular}{|c|c|c|c|c|c|}
\hline \multirow{3}{*}{ Career plans } & \multicolumn{3}{|c|}{ Year of study } & \multirow{2}{*}{\multicolumn{2}{|c|}{ Total }} \\
\hline & $\begin{array}{c}\mathrm{I} \\
(\mathrm{n}=40)\end{array}$ & $\begin{array}{c}\text { II } \\
(n=42)\end{array}$ & $\begin{array}{c}\text { III } \\
(\mathrm{n}=54)\end{array}$ & & \\
\hline & \multicolumn{3}{|c|}{$\%$} & $\mathrm{n}$ & $\%$ \\
\hline In a tourist facility & 57.5 & 57.1 & 46.0 & 72 & 53.0 \\
\hline In a recreational facility & 45.0 & 54.8 & 48.1 & 67 & 49.3 \\
\hline In a holiday resort ${ }^{*}$ & 45.0 & 66.7 & 33.3 & 64 & 47.1 \\
\hline $\begin{array}{l}\text { I am planning to stay abroad for a while to earn } \\
\text { some money }\end{array}$ & 40.0 & 38.1 & 25.9 & 40 & 29.4 \\
\hline In another profession related to physical education & 30.0 & 35.7 & 20.4 & 38 & 27.9 \\
\hline $\begin{array}{l}\text { In other institutions related to tourism and } \\
\text { recreation }\end{array}$ & 27.5 & 19.0 & 14.8 & 27 & 19.9 \\
\hline $\begin{array}{l}\text { I am planning to complete another supplementary } \\
\text { education }\end{array}$ & 27.5 & 26.2 & 14.8 & 24 & 17.6 \\
\hline $\begin{array}{l}\text { I would like to work in tourism and/or, but I don't } \\
\text { see any job opportunities" }\end{array}$ & 2.5 & 9.5 & 27.8 & 20 & 14.7 \\
\hline I am planning to go and stay abroad permanently & 15.0 & 9.5 & 9.3 & 15 & 11.0 \\
\hline A profession not related to tourism or recreation & 5.0 & 11.9 & 13.0 & 14 & 10.3 \\
\hline I haven't decided yet & 7.5 & 9.5 & 9.3 & 12 & 8.8 \\
\hline
\end{tabular}

${ }^{*}$ Statistical significance (planning a job in a holiday resort $-\mathrm{p}=0.005$ for test $\chi^{2}$; planning a job in tourism and/ or recreation, but there are no job opportunities $-\mathrm{p}=0.001$ for test $\chi^{2}$ ).

Source: author's own research.

There was a statistically significant difference between years of study and plans to work in tourist resorts $(\mathrm{p}=0.005)$. Willingness to work in a resort was expressed by almost half of the respondents (47.1\%). Future career in resorts was the most popular among $2^{\text {nd }}$-year students $(66.7 \%)$. The least interested in working in a resort were students of the third year $(33.3 \%)$. Proportion of $3^{\text {rd }}$-year students declaring such career plans was lower by $50 \%$ in comparison to $2^{\text {nd }}-$ year students.

$1^{\text {st }}$ - and $2^{\text {nd }}$-year students who planned their career in the industry assessed prospects of employment quite pessimistically ( 2.5 and $9.5 \%$, respectively). $3^{\text {rd }}$-year students were a little more optimistic $(27.8 \%)$. One in three students planned a temporary stay abroad to earn money (29.4\%). On average, every $10^{\text {th }}$ student wanted to work in a profession unrelated to tourism, planned to 
permanently live abroad or did not decide on their career plans (10.3, 11.0 and $8.8 \%$, respectively).

Based on the results from Table 4, statistically significant relationships were found between planning career in the tourism sector by $1^{\text {st }}-2^{\text {nd }}$ - and $3^{\text {rd }}$-year students and their career-oriented motivation - desire to work in the tourism sector $(\mathrm{p}=0.000)$.

Table 4

Relations between the reasons for studying and career plans* (Chi-squared test)

\begin{tabular}{|c|c|c|c|c|c|c|}
\hline \multirow{3}{*}{ Motives } & \multicolumn{6}{|c|}{ Career plans } \\
\hline & \multicolumn{3}{|c|}{ tourism sector } & \multicolumn{3}{|c|}{ recreation sector } \\
\hline & $1^{\text {st }}$ year & $2^{\text {nd }}$ year & $3^{\text {rd }}$ year & $1^{\text {st }}$ year & $2^{\text {nd }}$ year & $3^{\text {rd }}$ year \\
\hline Prospects of an interesting job & 0.041 & & & & & \\
\hline $\begin{array}{l}\text { Prospects of work in the tourism } \\
\text { sector }\end{array}$ & 0.001 & 0.000 & 0.001 & & & \\
\hline $\begin{array}{l}\text { Prospects of work in the recreation } \\
\text { sector }\end{array}$ & & & & 0.000 & 0.000 & 0.000 \\
\hline $\begin{array}{l}\text { Willingness to work in other } \\
\text { institutions }\end{array}$ & & & & & 0.043 & \\
\hline Interest in physical recreation & 0.002 & 0.001 & & 0.005 & 0.002 & 0.000 \\
\hline $\begin{array}{l}\text { Desire to promote a healthy lifestyle } \\
\text { through active recreation }\end{array}$ & & 0.020 & & & 0.014 & 0.004 \\
\hline Own experience of domestic travel & & & & & 0.014 & \\
\hline $\begin{array}{l}\text { Own experience of international } \\
\text { travel }\end{array}$ & & & & & & \\
\hline $\begin{array}{l}\text { Opportunity to develop own tourism } \\
\text { business }\end{array}$ & 0.037 & 0.026 & & 0.019 & & 0.013 \\
\hline $\begin{array}{l}\text { Opportunity to develop own } \\
\text { recreation business }\end{array}$ & 0.015 & 0.047 & & & 0.010 & 0.007 \\
\hline $\begin{array}{l}\text { Conviction of high prestige of the } \\
\text { profession }\end{array}$ & & & & & & \\
\hline $\begin{array}{l}\text { Major growth opportunities in the } \\
\text { tourism sector }\end{array}$ & & & & & 0.030 & \\
\hline
\end{tabular}

* For improved clarity of the results, the table contains only those variables and values which were statistically significant.

Source: author's own research.

$1^{\text {st }}$ and $2^{\text {nd }}$-year students who planned their career in the tourism sector were motivated by their interest in physical recreation $(p=0.002$ and $p=0.001$, respectively) and prospects of running their own business in the tourism sector $(\mathrm{p}=0.037$ and $p=0.026$, respectively) and recreation sector $(p=0.015$ and $p=0.047$, respectively). For students of $1^{\text {st }}$ to $3^{\text {rd }}$ year who planned career in recreation sector, choice of the field of study was motivated by their interest in physical recreation $(\mathrm{p}=0.005, \mathrm{p}=0.002$ and $\mathrm{p}=0.000$, respectively) and career in the recreation 
sector ( $p=0.000, p=0.000$ and $p=0.000$, respectively). $2^{\text {nd }}$ - and $3^{\text {rd }}$-year students who wanted a career in the recreation sector, listed career-oriented reasons behind choosing that particular field of study: desire to promote a healthy way of life through active recreation $(\mathrm{p}=0.014$ and $\mathrm{p}=0.004$, respectively), and prospects of running their own business in the recreation sector $(\mathrm{p}=0.010$ and $\mathrm{p}=0.007$, respectively). $2^{\text {nd }}$-year students were also motivated by career-oriented factors: great growth prospects in the tourism industry $(p=0.030)$, their own experience in domestic travel $(\mathrm{p}=0.014)$, their belief in the attractiveness of the field of study $(p=0.004)$, as well as autotelic desire to work in other institutions $(p=0.043)$ (Table 4).

It has been shown that $1^{\text {st }}$, $2^{\text {nd }}$ - and $3^{\text {rd }}$ - year students who planned their career in another profession related to physical culture were motivated by the following career-oriented factors: career in the recreation sector $(p=0.000, p=0.006$ and $\mathrm{p}=0.000$, respectively), interest in physical recreation $(\mathrm{p}=0.000, \mathrm{p}=0.002$ and $\mathrm{p}=0.008$, respectively) and desire to promote healthy lifestyle ( $\mathrm{p}=0.043$, $\mathrm{p}=0.014$ and $\mathrm{p}=0.026$, respectively). Additionally, $2^{\text {nd }}$-year students interested in working in another profession related to physical education, chose the discussed field of study based on their own experience in domestic travel $(p=0.002)$ and foreign travel $(p=0.002)$, prospects of running their own business in the recreation sector $(\mathrm{p}=0.010)$ and major growth opportunities in the tourism industry $(p=0.024)$. Meanwhile, $3^{\text {rd }}$-year students who wanted to work in another profession related to physical culture highlighted their belief in high prestige of the profession, interesting job opportunities and running their own recreation business as career-oriented motives ( $p=0.040, p=0.016$ and $p=0.003$, respectively).

Results related to career plans versus satisfaction from the studies are presented in Table 5 .

Table 5

Career plans of students versus their satisfaction with studies* (Chi-squared test)

\begin{tabular}{|l|c|c|c|c|c|c|}
\hline \multirow{2}{*}{ Career plans } & \multicolumn{3}{c|}{ Satisfaction } & \multicolumn{3}{c|}{ Choosing the faculty again } \\
\cline { 2 - 7 } & $1^{\text {st }}$ year & $2^{\text {nd }}$ year & $3^{\text {rd }}$ year & $1^{\text {st }}$ year & $2^{\text {nd }}$ year & $3^{\text {rd }}$ year \\
\hline Work in a recreation facility & & 0.050 & 0.037 & & 0.007 & 0.023 \\
\hline $\begin{array}{l}\text { Work in other tourism related } \\
\text { institutions }\end{array}$ & & & 0.024 & & & \\
\hline Work related to physical education & & & 0.009 & & & \\
\hline
\end{tabular}

* For improved clarity of the results, the table contains only those variables and values which were statistically significant.

Source: author's own research.

Career plans related to working in recreation sector $(p=0.037)$, other institutions related to tourism $(p=0.024)$ and physical education $(p=0.009)$ influenced 
$3^{\text {rd }}$-year students' satisfaction with studies to a significant extent. $2^{\text {nd }}-$ year students who planned career in the recreation sector also expressed satisfaction with their studies $(p=0.050)$. Future career in the recreation sector motivated the $2^{\text {nd }}$ - and $3^{\text {rd }}$-year students to believe that they would hypothetically select that field of study again ( $p=0.007$ and $p=0.023$, respectively). subjects.

Figure 1 presents employment prospects after graduation according to

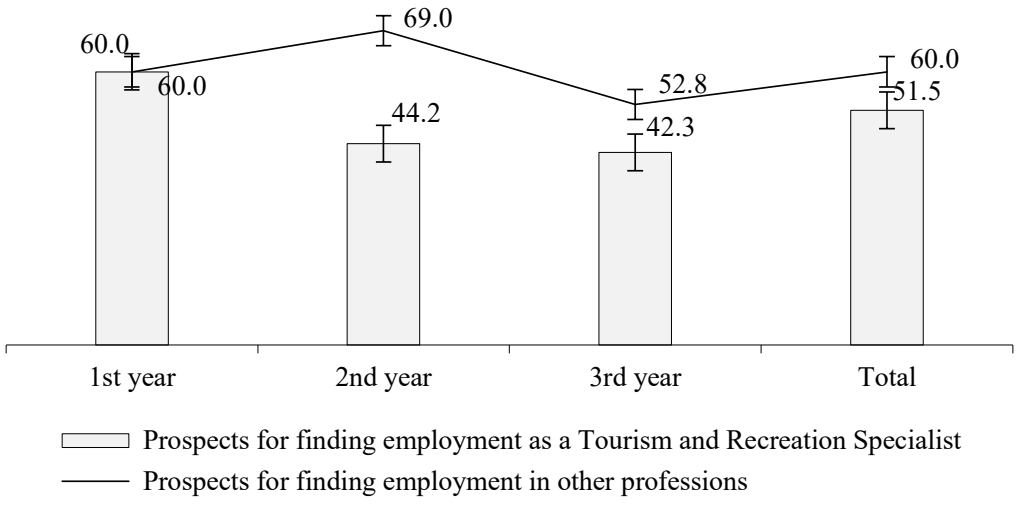

Figure 1. Employment prospects after graduation according to subjects (Chi-squared test)

Source: author's own research.

Assessment of career prospects in the field of Tourism and Recreation depended significantly on the year of studies $(\mathrm{p}=0.046) .51 .5 \%$ of subjects described prospects for finding employment as a Tourism and Recreation specialist as "average". There was a tendency to reduce belief in job opportunities with every successive year of study (10.0, 14.3 and $36.5 \%$, respectively). Every fifth subject $(21.6 \%)$ described prospects for finding employment as a Tourism and Recreation specialist as "poor". $23.9 \%$ of subjects described prospects for finding employment as a Tourism and Recreation specialist as "good", including $30 \%$ of $1^{\text {st }}$-year students, $26.2 \%$ of $2^{\text {nd }}$-year students and $17.3 \%$ of $3^{\text {rd }}$-year students. Thus, the lower year of studies, the more optimistic assessment of finding a job in the tourism industry.

Chances for finding a job in another profession were assessed similarly by students of all years. Every third respondent rated the chances of finding a job in another profession as "good" and "very good" $(29.6 \%) ; 3^{\text {rd }}$-year students gave that answer most frequently (35\%).

Assessment of satisfaction with studies among students of various years showed no statistically significant difference. Majority of students were satisfied 
with a chosen field of study (high and very high ratings accounted for $77.2 \%$ of responses). Students of all years reported a similar number of high and very high ratings 80,83 and $70 \%$, respectively. Only every twentieth respondent was not satisfied with their studies. "Low" and "very low" ratings accounted for $5.1 \%$ of responses and were given by $2^{\text {nd }}$ - and $3^{\text {rd }}$-year students $(2.3$ and $11.1 \%$, respectively).

Despite the overall satisfaction with the studies, majority of subjects (79.7\%) were uncertain about choosing (hypothetically) the field again. That uncertainty was declared mostly by $3^{\text {rd }}$-year students $(81.5 \%)$, while $1^{\text {st }}$ - and $2^{\text {nd }}$-year students were less apt to give that response (30 and $32 \%$, respectively). Only $16.7 \%$ were determined to choose Tourism and Recreation again; only $9.3 \%$ of $3^{\text {rd }}$-year students declared such hypothetical decision, compared to twice as many $1^{\text {st }}$ and $2^{\text {nd }}$-year students ( 21.1 and $22 \%$, respectively).

\section{Discussion}

Factors that impact our choices of a particular profession should be primarily: interest and passions (De Clercq, Honig, Martin, 2013; Vallerand et al., 2007). Ideally, by developing our interests, we can combine them with skills that improve job performance (Jarecki, 2008).

The study unveiled motives behind choosing Tourism and Recreation by undergraduate students at Kazimierz Wielki University in Bydgoszcz. The research showed two main reasons: development of one's interests (76.5\%) and promising job prospects $(54.4 \%)$. Prospects of an interesting job motivated most often $1^{\text {st }}$ and $2^{\text {nd }}$-year students. When choosing a field of study, these young people were motivated mostly by their interests, despite the prospective low wages in professions related to tourism and recreation.

Notably, the dominant motive behind choosing that particular field of studies was "romantic" and included also subsequent years of students. Passion for travel and desire to explore the world often stemmed from adventure novels and family stories. Perhaps that was the reason why fulfilling a dream of long journeys was so strongly reflected in students' responses. Although the passion was probably not as strong as described by a famous reporter and globetrotter Ryszard Kapuściński who said that "there is such a thing as being infected with travel and it is an incurable disease." Nevertheless, the belief that choosing that field of study facilitates traveling and learning about the world is certainly justified.

Confrontation of the obtained results with results of surveys conducted among students of the same major at the Faculty of Physical Education in Biała Podlaska showed significant convergence. Choosing undergraduate Tourism and Recreation studies, respondents were motivated mostly by their interests and attractiveness of the studies (Buchta, Skiert, 2008), while the graduate/Master's students were motivated by interests and career-oriented goals (Buchta, Skiert, 2009). 
In the study of Jarecki, based on an analysis of data from the Central Statistical Office from 2004 (which included a sample of approximately 4,000 households, students and graduates), different motivations were discovered (Jarecki, 2008). For people aged 30 and younger who studied and graduated, the most important motive to study was pragmatic - a chance to find a good job (almost $69 \%$ ). Development of one's interests was listed as the second reason (over $61 \%$ of subjects). The same study found that there were significant differences between the motivation of students from different fields. Better chances for a good job was the most important motive for Architecture and Construction students (over 82\%), as well as Economics and Administration (almost 80\%), while it was the least important for students of Agriculture, Forestry, Fishery (35\%) and Education/ Pedagogics (over 37\%). As for the second motive (i.e. personal interests), the largest proportion was discovered among Medicine students (100\% of respondents made such declarations), Education/Pedagogics (approximately 83\%) and Engineering and Technical (almost 72\%). The smallest proportion of subjects chose their studies according to their interests in fields such as Economics and Administration (approx. 55\%), Agriculture, Forestry and Fishery (60\%). It would be interesting to continue the research on the effects of higher education on e.g. performance, remuneration and job satisfaction when the field of study was convergent and divergent with one's interests.

Another important reason to choose a particular field of studies indicated by the respondents was a belief in the attractiveness of that field (39\% of subjects). These results correspond to the data analysis performed by other authors (Buchta, 2012; Radzińska, Nowak, Nowak, 2016a; Skiert, Buchta, 2014).

When starting to study of Tourism and Recreation, $34.6 \%$ of respondents were motivated by their plans associated with significant growth potential of the tourism industry and their willingness to run their own business in the tourism sector. Unfortunately, along the way students tended to lose their belief in possibility of running their own business in the industry $(42.5 \%, 35.7 \%$ and $22.2 \%$, respectively).

Interesting results were obtained in research carried out at the Off-Campus Faculty of Physical Education in Gorzów Wielkopolski, Tourism and Recreation. It revealed that "freshman" students paid particular attention to good preparation for the labor market in institutions connected directly with their field of study. These students also demonstrated great interest in running their own businesses (Radzińska, Nowak, Nowak, 2016a).

These results correspond to the current situation in the tourism industry, which has witnessed dynamic growth in recent decades. Tourist labor market has been leading the world in terms of generating workplaces. Tourism-based economy is an important market segment which employs $8.9 \%$ of all employed people in the world (Travel \& Tourism Economic Impact, 2014). The role of this sector in 
the Polish economy is much humbler but constantly growing. Employment in the tourism sector in 2013 amounted to 5.1\% of all employed Poles (Seweryn, 2015).

This study revealed that students are infrequently motivated by belief in high prestige of the profession (over 7\%). This is a puzzling result since the choice of future profession should take into account the aspect of prestige as a component of satisfying and fulfilling career. It may result from observations of the labor market in the tourism industry, which does not offer satisfactory earnings, although one can certainly list other occupations where wages are at a much lower level (nurses or salespeople). This situation should be food for thought for universities which educate tourism industry personnel, especially given the fact that every year the tourist services market in Poland expands. The results of previously mentioned Jarecki's research differ from the results of this study. An important motive for choosing the studies was the social prestige of being a graduate (approx. 27\%) (Jarecki, 2008).

Research of other authors on the prestige of teaching profession showed results similar to those obtained in this work - these motives were listed with least frequency (Radzińska, Nowak, Nowak, 2016a).

In this study, satisfaction with studies was expressed mainly by students of the third year whose choice of that particular field of study was motivated by sports: practicing qualified tourism, interest in physical recreation, and career-related plans - working in the recreation sector, as well as external motivations, such as being persuaded by friends. Other authors obtained data similar to those presented in this paper. The vast majority of students of Tourism and Recreation at the Off-Campus Faculty of Physical Education of Warsaw Academy of Physical Education in Biała Podlaska expressed satisfaction with their course and declared a hypothetical willingness to choose it again [9] - similarly to $96 \%$ of subjects at the Faculty of Physical Education in Biała Podlaska (Buchta, 2010) and over $83 \%$ of students from the Off-Campus Faculty of Physical Culture in Gorzów Wielkopolski (Radzińska, Nowak, Nowak, 2016b).

The highest proportion of students satisfied with their choice was observed in the fields of Medicine (93.1\%), while significantly lower satisfaction level was reported by students of Nursing (66.9\%) (Kropiwnicka, Orzechowska, Cholewska, Krajewska-Kułak, 2011).

In author's own study, majority of students (53\%) declared willingness to work in the recreation sector. The year of study significantly differentiated answers about the declared willingness to work in the tourism industry, while at the same time the subjects lacked belief in such possibility. The higher the year of study, the more negative assessment of employment prospects in the industry among students who wished to work in the industry. As a confirmation of this pessimistic view, one in three students planned a temporary stay abroad to earn money (29.4\%). Diminishing employment opportunities despite willingness to work in 
the profession seem to be a visible trend. It justifies plans of staying temporarily abroad of one third of students, while every tenth student intends to work outside tourism industry: live abroad permanently or have not decided about their professional future yet.

Jarecki (2008) noticed that - marginal at the time but visible now - the phenomenon of choosing field of studies which facilitates working abroad. Similarly, research by Radzińska et al. (2016b) showed that $38.9 \%$ of subjects planned to go abroad due to limited chances of finding a job as a Physical Education teacher.

Expanding the subject group in the future would allow for further verification of these observations. Exploring reasons behind studying in the context of professional goals and monitoring careers of Tourism and Recreation graduates seem crucial both for the students (who will become potential employees in the industry), as well as for potential candidates for students (professional and industry applications, practical preparation for working in the industry).

\section{Conclusions}

1. Students of Tourism and Recreation reported great passion for travel and prospects of an interesting job as their dominant motivation for this field of study.

2. An important reason behind choosing Tourism and Recreation was a prospect of running one's own business in the area.

3. Majority of subjects described prospects for finding employment as a Tourism and Recreation specialist as "average". There was a tendency to reduce the belief in job opportunities in successive years of study.

4. Professional plans and future work in a recreational unit motivated the $2^{\text {nd }}-$ and $3^{\text {rd }}$-year students to believe that they would hypothetically select this field of study again.

5. In order to meet the expectations of students, it is extremely important to adapt the curriculum of Tourism and Recreation courses to the actual needs of the modern economy.

\section{Bibliography}

Buchta, K. (2012). The competences of physical education students. Unified versus two-tier University studies. Polish Journal of Sport and Tourism, 19, 151-159.

Buchta, K. (2010). Graduate of the university of physical education in the labor market - start to professional career. Graduate in the labor market. Polish Journal of Sport and Tourism, 17, 46-47.

Buchta, K., Skiert, M. (2008). Assessment of professional qualifications and educational plans by tourism and recreation graduates. Polish Journal of Sport and Tourism, 15, 69-76.

Buchta, K., Skiert, M. (2009). Expectations of tourism and recreation students towards the course of education. Polish Journal of Sport and Tourism, 16 (4), 251-260.

De Carolis, D.M., Saparito, P. (2006). Social capital, cognition, and entrepreneurial opportunities: A Theoretical framework. Entrepreneurship Theory and Practice, 30, 41-56. 
De Clercq, D., Honig, B., Martin, B. (2013). The roles of learning orientation and passion for work in the formation of entrepreneurial intention. International Small Business Journal: Researching Entrepreneurship, 31 (6), 652-676.

Haczek, A., Kłos, A. (2012). Znaczenie postaw przedsiębiorczych przy wyborze kierunku studiów i planowaniu kariery zawodowej studentów ochrony środowiska oraz turystyki i rekreacji Uniwersytetu Pedagogicznego w Krakowie. Przedsiębiorczość - Edukacja, 8, 96-114.

Jarecki, W. (2008). Motywy wyboru studiów i kierunku studiów wyższych. Studia i Prace Wydziału Nauk Ekonomicznych i Zarządzania Uniwersytetu Szczecińskiego, 3, 143-153.

Kacprzak-Biernacka, E., Skura-Madziała, A., Kopański, Z., Brukwicka, I., Lishchynskyy, Y., Mazurek, M. (2014). Pojęcie motywacji, jej odmiany i podmioty motywacji. Journal of Clinical Healthcare, 1 (3), 2-5.

Klimkowska, K. (2014). Entrepreneurial Potential of the Students of Applied Linguistics Programme, Majoring in Translation. Academic Journal of Modern Philology, 3, 17-26.

Korpysa, J. (2008). Przedsiębiorczość w krajach Unii Europejskiej. Studia i Prace Wydziału Nauk Ekonomicznych i Zarządzania Uniwersytetu Szczecińskiego, 3, 23-35.

Kropiwnicka, E., Orzechowska, A., Cholewska, M., Krajewska-Kułak, E. (2011). Determinanty wyboru zawodu, poziom aspiracji oraz plany na przyszłość studentów kierunku lekarskiego i pielęgniarstwa Uniwersytetu Medycznego w Białymstoku. Problemy Pielęgniarstwa, 19 (1), $70-80$.

Krueger, N.F., Brazeal, D.V. (1994). Entrepreneurial Potential and Potential Entrepreneurs. Entrepreneurship Theory and Practice, 18 (3), 91-104.

Liberska, B. (1974). Problemy efektywności kształcenia wyższego. Warsaw: PWN.

Łubkowska, W., Eider, J. (2014). Uczelnie wyższe Szczecina jako potencjał regionu w aspekcie kształtowania innowacyjności. Handel Wewnętrzny, 5 (352), 123-137.

Łubkowska, W., Nadobnik, J., Tarnowski, M., Nowak, M.A. (2017). Samoocena wiedzy, umiejętności zawodowych i kompetencji społecznych studentów podstawą ewaluacji programu studiów kierunku turystyka i rekreacja. Prace Naukowe Akademii im. Jana Dlugosza w Czesstochowie. Kultura Fizyczna, 16 (4), 145-161.

Nadobnik, J., Tarnowski, M., Nowak, M.A. (2017). Motives for choosing studies as predictors of career plans of tourism and recreation students. Central European Journal of Sport Sciences Medicine., 18 (2), 107-118.

Obuchowski, K. (1993). The search for human attributes. Delft (Niederlande): Eburan Publisher, Series in Behavioural Science.

Paczyńska-Jędrycka, M., Łubkowska, W., Jońca, M. (2015). Shaping social competences and social capital in children and adolescents by means of non-formal education methods and techniques. Service Management, 15 (1), 67-75.

Radzińska, M., Nowak, L., Nowak, M.A. (2016a). Motives for commencing studies and expectations concerning professional competence in students who practice, used to practice or have never practiced sport. Central European Journal of Sport Sciences Medicine, 13 (1), 37-45.

Radzińska, M., Nowak, L., Nowak, M.A. (2016b). Satysfakcja z wyboru studiów a zamierzenia zawodowe studentów wychowania fizycznego. Prace Naukowe Akademii im. J. Dlugosza w Częstochowie. Kultura Fizyczna, 15 (2), 109-124. 
Seweryn, R. (2015). Wkład turystyki w tworzenie miejsc pracy w Polsce na tle wybranych krajów Unii Europejskiej po 1989 roku. Nierówności Społeczne a Wzrost Gospodarczy, 41 (1), 390-399.

Skiert, M., Buchta, K. (2014). Student kierunku turystyka i rekreacja jako konsument usługi edukacyjnej w uczelni wychowania fizycznego. Zeszyty Naukowe Uniwersytetu Szczecińskiego, 825, Problemy Zarządzania, Finansów i Marketingu, 36, 159-170.

Szark-Eckardt, M., Augustyńska, B., Łubkowska, W, Nowak, M.A. (2017). Motywy wyboru studiów, satysfakcja z nich oraz plany zawodowe studentów turystyki i rekreacji Uniwersytetu Kazimierza Wielkiego w Bydgoszczy. Zeszyty Naukowe Uniwersytetu Szczecińskiego Ekonomiczne Problemy Turystyki, 1 (37), 101-111.

Travel \& Tourism Economic Impact 2014. (2014). London: World Travel \& Tourism Council.

Vallerand, R.J., Salvy, S.J., Mageau, G.A., Elliot, A.J., Denis, P.L., Grouzet, F.M.E., Blanchard, C. (2007). On the role of passion in performance. Journal of Personality, 75 (3), 505-534.

\section{Motywy studiowania i plany zawodowe studentów turystyki i rekreacji pierwszego stopnia}

Słowa kluczowe: motywacje, wybór kierunków studiów, zadowolenie ze studiów, plany zawodowe

Streszczenie. Celem artykułu było określenie motywów studiowania oraz poznanie planów zawodowych studentów turystyki i rekreacji pierwszego stopnia na Uniwersytecie Kazimierza Wielkiego w Bydgoszczy. Zastosowano kwestionariusz ankietowy własnego autorstwa. We wnioskowaniu statystycznym posłużono się frekwencją cech oraz testem niezależności chi-kwadrat. Celowym doborem objęto 136 respondentów $(69 \%$ kobiet i $31 \%$ mężczyzn). Analiza wpływu roku studiów na motywy wyboru kierunku studiów wykazała istotną statystycznie różnicę w oczekiwaniach studentów I, II i III roku w zakresie perspektywy ciekawej pracy $(\mathrm{p}=0,033)$. Stwierdzono statystycznie istotne zależności wśród studentów poszczególnych lat w planach związanych z dużymi możliwościami rozwoju w branży turystycznej $(\mathrm{p}=0,028)$. Ważnym motywem podjęcia studiów i studiowania na kierunku turystyka i rekreacji była możliwość rozwijania samodzielnej działalności gospodarczej w tej dziedzinie. Prozawodowe motywy studiowania i wiązanie swojej przyszłości zawodowej z pracą w jednostce rekreacyjnej determinowały przekonanie o ewentualnym ponownym wyborze studiów studentów II oraz III roku. Wychodząc naprzeciw oczekiwaniom studentów, niezwykle ważne jest dostosowanie programów nauczania na kierunkach turystyki i rekreacji do potrzeb współczesnej gospodarki.

\section{Citation}

Szark-Eckardt, M., Augustyńska, B., Łubkowska, W. (2017). Reasons behind Studying Tourism and Recreation and Career Plans of Undergraduate Students. Marketing i Zarzadzanie, 4 (50), 73-88. DOI: $10.18276 / \mathrm{pzfm} .2017 .50-05$. 